\title{
Detection of Varicosavirus and Ophiovirus in Lettuce Associated with Lettuce Big-Vein Symptoms in Brazil
}

\author{
Addolorata Colariccio ${ }^{1}$, Alexandre L.R. Chaves ${ }^{1}$, Marcelo Eiras ${ }^{1}$, César M. Chagas ${ }^{1}$ \& Piero Roggero ${ }^{2}$ \\ ${ }^{1}$ Centro de Pesquisa e Desenvolvimento de Sanidade Vegetal, Instituto Biológico, Av. Conselheiro Rodrigues Alves, 1252, \\ CEP 04014-002, São Paulo, SP, Brazil, e-mail: colariccio@biologico.sp.gov.br, ${ }^{2}$ Istituto di Virologia Vegetale/CNR, Torino, \\ Itália
}

(Accepted for publication on 14/04/2005)

Corresponding author: Addolorata Colariccio

COLARICCIO, A., CHAVES, A.L.R., EIRAS, M., CHAGAS, C.M. \& ROGGERO, P. Detection of Varicosavirus and Ophiovirus in lettuce associated with lettuce big-vein symptoms in Brazil. Fitopatologia Brasileira 30:416-419. 2005.

\begin{abstract}
During surveys undertaken from 1998 to 2003 in the major vegetable growing areas of the city of São Paulo green belt, lettuce (Lactuca sativa) and endive (Cichorium endivia) plants were observed, which showed chlorotic thickening of foliar veins, defective growth and, in some cases, failure to form complete heads. Biological and serological [DAS-Enzyme linked immunosorbent assay (Elisa)] tests together with electron microscope observations, revealed the presence of Lettuce big-vein virus and Mirafiori lettuce virus, in these plants both responsible for the lettuce big-vein syndrome.

Additional keywords: Lettuce big-vein associated virus, Mirafiori lettuce virus, lettuce, virus transmitted by fungi.

\section{RESUMO}

Detecção de Varicosavirus e Ophiovirus associados à síndrome do espessamento clorótico das nervuras da alface no Brasil

Em levantamentos realizados entre 1998 e 2003, nas principais regiões produtoras de alface (Lactuca sativa) e escarola (Cichorium endivia) no cinturão verde de São Paulo, foram observados sintomas de espessamento de nervuras foliares, clorose, crescimento irregular e ausência de formação da cabeça. Por meio de testes biológicos, DAS-Enzyme linked immunosorbent assay (Elisa) e microscopia eletrônica de transmissão constatou-se a presença do Lettuce big-vein associated virus e Mirafiori lettuce virus, responsáveis pela síndrome do espessamento clorótico das nervuras da alface ("lettuce bigvein").
\end{abstract}

Palavras-chave adicionais: Lettuce big-vein associated virus, Mirafiori lettuce virus, alface, virus transmitido por fungos.

In 1998, in the vegetable growing areas of São Paulo's green belt, big-vein symptoms were observed in lettuce (Lactuca sativa L.) cultivated in soil or hydroponically, especially during the cooler season. Lettuce big-vein is an important soil-borne viral disease transmitted by the chytrid fungus Olpidium brassicae (Wor.) Dang. It is characterized by typical symptoms of thickened veins, foliar clearing areas parallel to the midrib, and vein clearing and shrinking, resulting in poor quality plants with reduced market value. The disease is commonly present at temperatures below 20 ${ }^{\circ} \mathrm{C}$, a condition frequently observed in temperate climates. The big-vein syndrome is known by this name because its typical symptoms runs parallel to the main vein (Falk, 1997). The cause of this syndrome was attributed to Lettuce bigvein associated virus (LBVV) which belongs to the genus Varicosavirus. It has rod-shaped particles measuring from 320 to $360 \mathrm{~nm}$ and is related to Tobacco stunt virus (TStV) (Kuwata et al., 1983; Kuwata \& Kubo 1984; Vetten et al., 1987). According to Roggero et al. (2000), a virus from the genus Ophiovirus, named Mirafiori lettuce virus (MiLV) was reported to be the causal agent of big-vein symptoms and the formerly described LBVV only caused latent infection, while no synergism was observed with mixed infection by these two unrelated viruses. The MiLV has been also reported on lettuce from European countries, the USA and Japan (Roggero et al., 2000, 2002). Both viruses, MiLV and LBVV, are common in mixed infection in lettuce samples from Northern Italy and France (Roggero et al., 2003). Recently, the same situation was reported in Brazil (Colariccio et al., 2003; Lima Neto et al., 2004). In surveys undertaken between 1998 and 2003, typical big-vein symptoms (Figure 1A) were observed inthe State of São Paulo that affect different lettuce cultivars, either grown directly in the soil or hydroponically. Leaves and roots of different lettuce cultivars ('Elisa', 'Hortensia', 'Lady', 'Regina', 'Ryder' and 'Verônica'), endive (Cichorium endivia L. 'Eliseé' and 'Frevola') and the weeds Emilia sagitatta (Vahl) DC., Galinsoga parviflora Cav., Sonchus asper (L.) Hill and S. oleraceous L., were collected in the municipalities of Arujá, Atibaia, Biritiba-Mirim, Cotia, Embu-Guaçu, Guararema, Guarulhos, Itapecerica da Serra, Jacareí, Mogi das Cruzes, Monte Alegre do Sul and Vargem Grande Paulista. All 


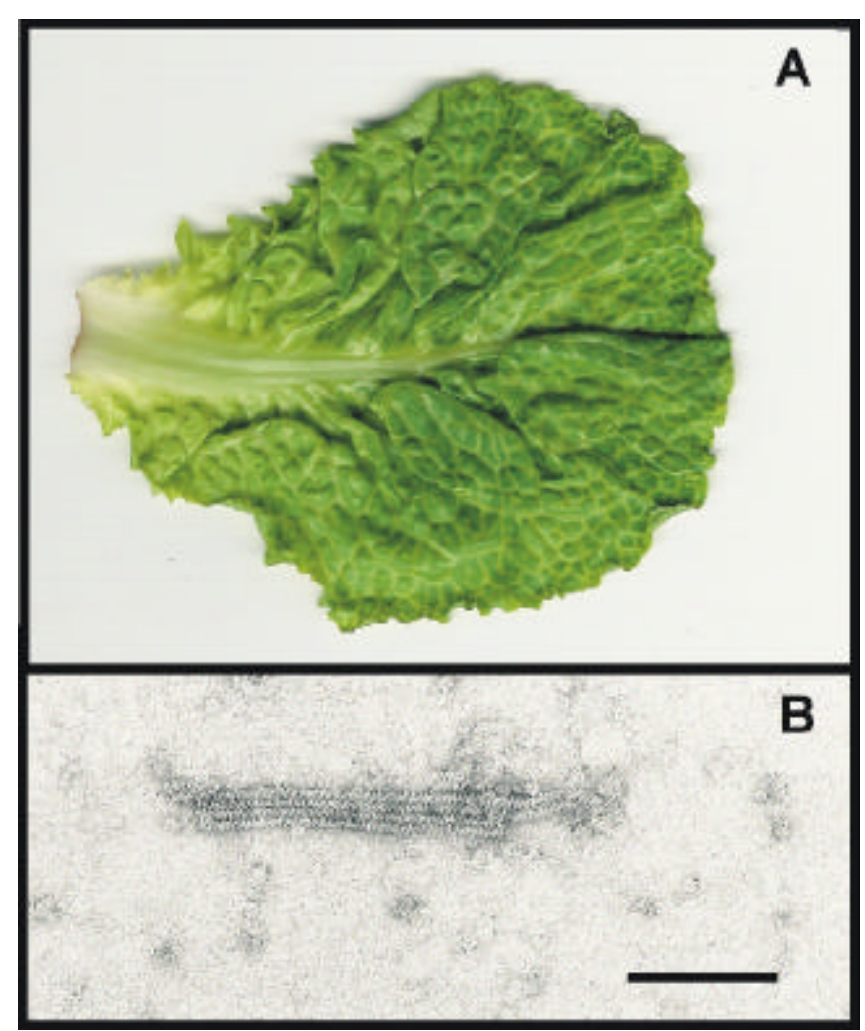

FIG. 1 - Big-vein symptom on lettuce (Lactuca sativa) (A) and electron micrograph of negatively stained Lettuce big-vein virus particles. Bar: 100nm (B)

samples were submitted to biological and serological tests, and transmission electron microscope observations. For mechanical transmission, leaf or root tissues from each lettuce cultivar were homogenized with extraction buffer $(50 \mathrm{mM}$ phosphate buffer $\mathrm{pH} 7.0$ containing $1 \mathrm{mM}$ Na-EDTA, $5 \mathrm{mM}$ Na-DIECA, $5 \mathrm{mM}$ Na-thioglycolate and $50 \mathrm{mg} / \mathrm{ml}$ activated charcoal) (1/5 w/v) in a cooled mortar (Roggero et al., 2000). Crude sap was mechanically inoculated on leaves of Chenopodium amaranticolor Coste \& Ryan, C. quinoa Willd., Nicotiana benthamiana Domin., N. occidentalis Wheeler and of the commercial lettuce cultivars 'Hortensia', 'Regina', 'Verônica'. Soil samples collected in these regions were tested for 'Hortensia' lettuce seedlings germination in greenhouse conditions. All samples (six weeds, nine endives and 171 lettuce cultivars) were tested by DAS-Enzyme linked immunosorbent assay (Elisa), with antiserum specific to MiLV and LBVV, according to Roggero et al. (2000).

In the presence of MiLV alone or MiLV and LBVV in mixed infection were detected in the lettuce samples with big-vein symptoms. No symptoms were found in lettuce infected by LBVV alone. Some weeds from lettuce growing areas (Table 1), which showed mosaic symptoms, were infected with LBVV alone. The lettuce symptoms were observed mainly during the cooler season (from June to September), when daytime temperatures range from $22{ }^{\circ} \mathrm{C}$ to $18^{\circ} \mathrm{C}$ at and nighttime from $16^{\circ} \mathrm{C}$ to $10^{\circ} \mathrm{C}$. In the States of São Paulo and Paraná, in Brazil, MiLV alone was detected by Elisa in some lettuce samples with big-vein symptoms, while only LBVV was detected in lettuce samples not showing big-vein symptoms. Leaf fragments of lettuce with symptoms were homogenized at $4{ }^{\circ} \mathrm{C}$ in $5 \%$ gluteraldehyde in phosphate buffer $\mathrm{pH} 7.0$, negatively stained with $2 \%$ uranyl acetate and examined in a Phillips EM 208 electron microscope. Samples of healthy lettuce were used as control.

Results of mechanical transmission were negative for all tested samples, probably due to the fact that experiments had been carried out in the greenhouse at temperatures above $18{ }^{\circ} \mathrm{C}$, as observed by Lot et al. (2002). In DAS-Elisa, 51\% of the all samples (weeds, endives and lettuce) reacted positively with MiLV or LBVV. From the lettuce samples, $31.2 \%$ and $2.15 \%$ were infected, respectively, with both viruses or with MiLV alone, whereas $15.6 \%$ of the symptomless samples were infected with LBVV (Table 1). These results agree with those described by Lot et al. (2002). The only samples that reacted positively against LBVV wee one of $S$. oleraceous with growth reduction and foliar mosaic, and one of endive with mosaic. So far, the occurrence of $S$. oleraceous and $S$. asper as LBVV reservoirs has been reported in several countries (Brunt et al., 1997).

No ophiovirus like-particles were seen in the electron microscope of affected lettuce extracts, although LBVV particles (Figure 1B) were observed in a few symptomatic lettuce samples in which MiLV and LBVV were detected by Elisa. The MiLV particle observation may have failed due to virus lability, as first related by Roggero et al. (2000). Thus, the situation encountered in our surveys in the subtropical areas of Brazil (Colariccio et al., 2003) is similar to that found in the European temperate climate, with the presence of both viruses. It is worth mentioning that in terms of epidemiological aspects, $O$. brassicae was reported in the central region of Brazil as a vector of the Squash necrosis virus (Lin, 1979; 1984). In a survey carried out in different regions, big-vein symptoms were observed in lettuce, mainly in cultivated higher plains areas and rarely in low flat lands. The fungi vectoring viruses belong to two classes: Chytridiomycetes (genus Olpidium) and Plasmodiophoromycetes (genera Polymyxa and Spongospora). Olpidium brassicae is a vector of minor importance compared to insects, although under favorable conditions it can spread important plant viruses (Costa, 1999) as in the case of LBBV and MiLV (Roggero et al., 2000). In São Paulo and Paraná States, MiLV alone was detected by Elisa in some lettuce samples with big-vein symptoms, and LBVV was detected in some symptomless samples (Colariccio et al., 2003; Lima Neto et al., 2004).

The $O$. brassicae is an obliged parasite whose zoospores commonly infect roots, mainly in wet and cool soil conditions (Costa, 1999). Lettuce big-vein symptoms were observed in conventional and hydroponic lettuce under these conditions during the winter months in São Paulo. The low dissemination of these viruses to neighboring areas is due to the slowmobility of the zoospores and to the 


\section{A. Colariccio et al.}

TABLE 1 - Results of DAS-Enzyme linked immunosorbent assay (ELISA) of lettuce (Lactuca sativa) samples with virus symptoms collected in São Paulo's green belt regions against antiserum specific to Lettuce big-vein virus (LBVV) and Mirafiori lettuce virus (MiLV)

\begin{tabular}{|c|c|c|c|c|c|}
\hline \multirow{2}{*}{ Region } & \multirow{2}{*}{ Specie/Cultivar } & \multirow{2}{*}{ Sample $(H / I)^{*}$} & \multirow{2}{*}{ Symptom** } & \multicolumn{2}{|c|}{ DAS-ELISA ${ }^{* * *}$} \\
\hline & & & & LBVV & MiLV \\
\hline Arujá & Lactuca .sativa/Hortensia & $4 / 4$ & $\mathrm{BV}$ & + & + \\
\hline \multirow[t]{4}{*}{ Atibaia } & L.sativa/Hortensia & $18 / 5$ & $\mathrm{BV}$ & + & + \\
\hline & L.satìva/Hyder & $5 / 2$ & NS & + & - \\
\hline & L sativa/Lady & $4 / 2$ & NS & + & - \\
\hline & Cichoria endivia/Frevola & $1 / 1$ & BV & + & + \\
\hline \multirow[t]{4}{*}{ Biritiba Mirim } & L sativa/Ryder & $5 / 0$ & NS & - & - \\
\hline & L sativa /Hortensia & $6 / 1$ & NS & + & - \\
\hline & L sativa/Hortensia & $3 / 2$ & $\mathrm{BV}$ & - & + \\
\hline & L sativa / Regina & $4 / 2$ & $\mathrm{BV}$ & + & + \\
\hline Cotia & L sativa/Hortensia & $3 / 1$ & $\mathrm{BV}$ & + & + \\
\hline Embu-Guaçu & L sativa /Hortensia & $3 / 3$ & BV & + & + \\
\hline Guararema & L sativa/Hortensia & $2 / 2$ & $\mathrm{BV}$ & + & + \\
\hline \multirow{9}{*}{ Guarulhos } & L.sativa/Elisa & $10 / 0$ & NS & - & - \\
\hline & L.sativa /Elisa & $7 / 3$ & NS & + & - \\
\hline & L.sativa/Hortensia & $4 / 1$ & BV & + & + \\
\hline & L sativa /Hortensia & $6 / 5$ & NS & + & - \\
\hline & L sativa/Hortensia & $4 / 4$ & BV & + & + \\
\hline & Emilia sagitata & $1 / 0$ & NS & - & - \\
\hline & Galinsoga parviflora & $1 / 0$ & NS & - & - \\
\hline & Sonchus asper & $1 / 0$ & NS & - & - \\
\hline & S. oleraceus & $3 / 1$ & $\mathrm{M}$ & + & - \\
\hline \multirow[t]{2}{*}{ Itapecerica da Serra } & L sativa/ Verônica ${ }^{\mathbf{h}}$ & $7 / 3$ & NS & + & - \\
\hline & C. endivia/Eliseé & $3 / 1$ & $\mathrm{BV}$ & + & + \\
\hline \multirow[t]{4}{*}{ JacareÍ } & C. endivia/Eliseé & $5 / 1$ & M & + & - \\
\hline & L.sativa / Ryder & $3 / 1$ & NS & + & - \\
\hline & L.sativa/Ryder & $2 / 1$ & NS & + & - \\
\hline & L sativa/Lady & $1 / 1$ & NS & + & - \\
\hline Mogi das Cruzes & L.sativa/Elisa & $6 / 6$ & BV & + & + \\
\hline \multirow[t]{4}{*}{ M. Alegre do Sul } & L sativa/Hortensia & $5 / 0$ & NS & - & - \\
\hline & L.sativa/ Hortensia & $27 / 24$ & $\mathrm{BV}$ & + & + \\
\hline & L sativa/ Hortensia & $10 / 8$ & NS & + & - \\
\hline & L.sativa/ Hortensia & $5 / 2$ & BV & - & + \\
\hline \multirow[t]{2}{*}{ V. Grande Paulista } & L sativa/ Verônica & $6 / 2$ & NS & + & - \\
\hline & L sativiva/ Verônica ${ }^{\mathbf{h}}$ & $11 / 6$ & $\mathrm{BV}$ & + & + \\
\hline TOTAL & & $186 / 95(51,0 \%)$ & & & \\
\hline
\end{tabular}

interdependence of rain, dew and irrigation, as well as its highly unstable condittion outside of the host (Costa, 1999).

The presence in $S$. oleraceous in lettuce crops from São Paulo could be related to spread of big-vein under our conditions as occurred in the North Hemisphere where $S$. oleraceous and $S$. aster were described as LBVV natural reservoirs (Brunt et al., 1997). The fact that both weeds are present in Brazil, may indicate they constitute the same reservoirs here.

The incidence of MiLV and LBVV in Brazil (Colariccio et al., 2003) and later in Chile (Rosales et al., 2004) suggests the possibility of their presence in other temperate and sub-tropical South American countries.

\section{LITERATURE CITED}

BRUNT, A.A., CRABTREE, K., DALlWITZ, M.J., GIBBS, A.J. \& WATSON, L. Viruses of plants. Wallingford, UK. CAB International. 1997.
COLARICCIO, A., CHAVES, A.L.R., EIRAS, M., CHAGAS, C.M., LENZI, R. \& ROGGERO, P. Presence of lettuce big-vein and associated viruses in a subtropical area of Brazil. New Disease Report 7:1-2. 2003.

COSTA, C.L. Vetores de vírus de plantas II - Fungos, Nematóides e Ácaros. Revisão Anual de Patologia de Plantas 7:213-258. 1999.

FALK, B.W. lettuce big-vein. In: Davis, R.M., Subbarao, K.V., Raid, R.N. \& Kurtz, E.A. (Eds) Compendium of lettuce disease. St Paul. APS Press. 1997. pp.41-42.

KUWATA, S. \& KUBO, S. Properties of two Olpidium-transmitted viruses: Tobacco stunt and lettuce big-vein. Anais $6^{\text {th }}$ International Congress Virology, Sendai. 1984. p.331.

KUWATA, S., KUBO, S., YAMASHITA,S. \& DOI, Y. Rod-shaped particles, a problable entity of lettuce big vein virus. Annual Phytopathology Sociedad Japan 49:246-251. 1983.

LIMA NETO, V. da C., COLARICCIO, A., CHAVES, A.L.R., STRAPASSON, M., CHAGAS, C.M. \& ROGGERO, P. Ocorrência de Varicosavirus e Ophiovirus associados ao espessamento clorótico das nervuras da alface no estado do Paraná. Summa 
Detection of Varicosavirus and Ophiovirus in lettuce associated with...

Phytopathologica 30: 83-84. 2004 (Resumo).

LIN, M.T. Occurrence and host range of Olpidium brassicae in Central Brazil. Plant Disease Report 63:10-12. 1979.

LIN, M. T. Transmissão de vírus de plantas por fungos. In: VI Colóquio de Virologia Vegetal. Fitopatologia Brasileira 9:306-307, 1984.

LOT, H., CAMPBELl, R.N., SOUCHE, S., MILNE, R.G. \& ROGGERO, P. Transmission by Olpidium brassicae of Mirafiori lettuce virus and Lettuce big-vein virus, and their roles in lettuce big-vein etiology. Phytopathology 92:288-293. 2002.

ROGGERO, P., LOT, H., SOUCHE, S., LENZI, R. \& MILNE, R.G. Occurrence of Mirafiore lettuce virus and Lettuce big-vein virus in relation to development of big-vein symptoms in lettuce crops. European Journal of Plant Pathology 109:261-267. 2003.

RogGero, P., CIUfFO, VAIRA, A.M., ACCOTTO, G.P., MASENGA, V. \& MILNE, R.G. An Ophiovirus isolated from lettuce with big-vein symptoms. Archives of Virology 145:2629-2642. 2000.

ROSALES, M., SEPULVEDA, P. \& BRUNA, A. First report Lettuce big-vein virus and Mirafiori lettuce virus in Chile. Plant Disease 88:1286. 2004.

VETTEN, H.J., LESEMANN, D.E. \& DALCHOW, J. Electron microscopical and sorological detection of virus-like particles associated with lettuce big-vein disease. Journal Phytopathology 120:53-59. 1987. 